Meta

Journal des tradlucteurs

Translators' Journal

\title{
International Conference on Interpretation: What Do We Know and How?
}

\section{Sylvie Lambert}

Volume 40, numéro 1, mars 1995

URI : https://id.erudit.org/iderudit/003386ar

DOI : https://doi.org/10.7202/003386ar

Aller au sommaire du numéro

Éditeur(s)

Les Presses de l'Université de Montréal

ISSN

0026-0452 (imprimé)

1492-1421 (numérique)

Découvrir la revue

Citer cette note

Lambert, S. (1995). International Conference on Interpretation: What Do We

Know and How? Meta, 40(1), 185-186. https://doi.org/10.7202/003386ar d'utilisation que vous pouvez consulter en ligne.

https://apropos.erudit.org/fr/usagers/politique-dutilisation/ 


\section{INTERNATIONAL CONFERENCE ON INTERPRETATION: WHAT DO WE KNOW ANO HOW?}

At long last, nearly two decades after the first conference on interpretation held in Venice. Italy, in 1976 (see Gerver and Sinaiko, Language Interpretation and Communication, 1978: Plenum Press), and 8 years following the second one on conference interpretation which took place in Trieste, in 1986, a third conference on interpretation was held this summer in Turku. Finland. The conference, officially entitled "The International Conference on Interpretation: What do we know and how?" was held at the University of Turku from August 25-27. 1994.

The organizers included the Centre for Translation and Interpreting (University of Turku), l'Institut Supérieur d'Interprétation el de Traduction IISIT. Paris), and la Scuola Superiore di Lingue Moderne per Interpreti e Tradutlori (SSLMT. Trieste).

In addition lo being held in spectacular surroundings, the conference met at a time which seemed most convenient for both European and North American participants, most of whom resume teaching one month earlier that their European colleagues. Other considerations worthy of mention include the fact that the organizers planned the conference so that the maximum possible time be made available for constructive discussion: 10 this effect. speakers did not read their actual papers. Instead, their short presentation (5-8 munutes) in each session (see below) was followed by a debate during or following which the discussion was open to the audience.

Furthermore. there were no parallel sessions: in other words no participant ever felt that he or she might be missing on something important going on in another room. Poster presentations were also made available from the very first day and remained on display during the entire three-day conference.

Finally, an open-hook exhibilon displayed the works of three publishers, namely John Benjamins. W. De Gruyter and Edituons Rodophı B.V. The actual proceedings of the Turku conference are currently in preparation.

For the benefit of the readers who were unable to be present in Turku. the aim of the conference was to discuss the following questions

What contribution do psycho- and neurolinguistics, discourse analysis, cognitive sciences. communication studies, semiotics, and translation studies make to interpretation and vice-versal?

- Can we renew the theoretical and methodological approach to interpretation or is interpretation only an applied field of research?

- How to develop transdisciplinary models for different types of interpretation, namely consecutive, simultaneous. courn. community, relay and liaison interpreting??
In order to elicit as many answers to the above. mentioned questions, careful planning and organization went into the following formats:

- Three plenary sessions included Neurolinguisties and Interpretation (Laura Gran and Franco Fabhro). Coknitive Psychology and Interpretation (Alber Tijus) and Communication Studies and Interpretation (Per l.inell).

- Two round lables. one on research policy and the other on the interaction between research and training.

- Finally. six workshops dealt with such issues as methodology: quality in conference performance: quality in interpreting for the media, court, etc.: skill components: discourse analysis and interpreting: and intercultural communication, negotiation and interpreting.

The conference was iruly extremely well organized. From the format of the presentations, to the information participants received prior to the conference. to smaller details, such as the possibility of having lunch on the premises, and having sludents available to cater to our every need, this was truly one of the best organised conferences I have ever attended.

Furthermore, the setting was ideal to meet new people or renew old acquaintances. It became very apparent that the contacts which were being estab lished. renewed or strengthened seem vital. On the one hand. I came away with the feeling that ten years was possibly $((x)$ long a gap hetween conferences on interpretation. although some of the participants rub shoulders more frequently by attending AIIC or ATA meetings in between.

Through no fault on the part of the organizers. my only criticism is directed at the disparity in the quality of the presentations: in other words, some were well-planned and lighlly controlled. whereas others appeared amateurish and almost ad-libbed. There had also been some last-minute changes and/or cancellations on the part of some participants. which meant some very rapid thinking on the part of the organizers who reshuffled speakers and programmes very smoothly. again. through no fault of their own. It was hecause of the care and thoughtful planning that had obviously gone into the overall formattong of this conference that everytheng went without a hitch in the end

Nevertheless, tension was present. I gathered this information from several non-interpreter colleagues. Non-interpreters who are not accustomed to mingling with interpreters. reported to me that they noticed tangible tension at the conference. As a non-interpreter who has had the privilege of attending all three conferences on interpretalion. I noticed nothing unusual.

I was struck by other factors: judging by some of the questions coming from the audience. I felt that the gap between the theoretical and vocational facets of conference interpretation had not been bridged. For example. I was personally disappointed to see that 
after all this time, and all the research that has been carried out, some minds were still stuck on such questions as whether one should interpret into or from one's mother-tongue, and why exercises such as shadowing had not been banned once and for all. One plenary speaker even went so far as to make a humorous allusion to the so-called "Masters of Truth" in inter. pretation. probably a reference to certain old-fashioned thinkers and their stubborm attitudes towards their profession.

Other participants felt that there should be no need to force a dichotomy between experimental and practical observations when carrying research on interpretation. One does not always need an experiment to advance sound hypotheses or make tentative observations, provided they do not hecome the "Truths" expounded upon by the "Masters". By the same token, the same can be said for scientific experimentation: observations are necessary otherwise we would not be in a position to actually formulate the questions! Conferences such as these are crucial for breaking down barriers between fields.

All in all. I was delighted to be able to attend and participate at such a conference and felt that I had met some wonderful new contacts. Mention should be made of the dinner party the night hefore the last day of the conference where we were served typical Finnish cuisine which included elk, reindeer and salmon.

SYLVIE LAMBERT Unversity of Orraw'a. Otran'a. Canada 